OPEN ACCESS

Edited by:

Adrià Muntaner Mas,

Government of the Balearic Islands,

Spain

Reviewed by:

María Belén San Pedro Veledo,

Universidad de Oviedo, Spain

Nuria Puig,

National Institute of Physical Education of Catalonia (INEFC), Spain Inés López Manrique,

Universidad de Oviedo, Spain

*Correspondence:

Pedro Gil-Madrona

Pedro.Gil@uclm.es

Guillermo F. López-Sánchez gfls@um.es

Specialty section: This article was submitted to Movement Science and Sport Psychology,

a section of the journal

Frontiers in Psychology

Received: 14 May 2019

Accepted: 15 August 2019 Published: 20 September 2019

Citation:

Gil-Madrona $P$

Gutiérrez-Marín EC, Cupani M, Samalot-Rivera A, Díaz-Suárez A and López-Sánchez GF (2019) The Effects of an Appropriate Behavior Program on Elementary School Children Social

Skills Development in Physical

Education. Front. Psychol. 10:1998. doi: 10.3389/fpsyg.2019.01998

\section{The Effects of an Appropriate Behavior Program on Elementary School Children Social Skills Development in Physical Education}

\author{
Pedro Gil-Madrona ${ }^{1 *}$, Eva Cristina Gutiérrez-Marin ${ }^{1}$, Marcos Cupani2, \\ Amaury Samalot-Rivera ${ }^{3}$, Arturo Díaz-Suárez ${ }^{4}$ and Guillermo F. López-Sánchez ${ }^{4 *}$ \\ ${ }^{1}$ Faculty of Education of Albacete, University of Castilla-La Mancha, Albacete, Spain, ${ }^{2}$ Universidad Nacional de Córdoba, \\ Córdoba, Argentina, ${ }^{3}$ The College at Brockport, The State University of New York, New York, NY, United States, ${ }^{4}$ Faculty \\ of Sport Sciences, University of Murcia, Murcia, Spain
}

The purpose of this study was to see the effects of an appropriate behavior development program in relation to the improvement of fair play and social skills behaviors of elementary school children during the physical education class. The participants of this study were 204 students from 5th and 6th grade from seven different public schools in Castilla-La Mancha, Spain. Data was collected through a questionnaire to measure students' pre and post appropriate behaviors when winning, appropriate behaviors when loosing, appropriate behaviors during the game, fair play skills and social skills, during the physical education class. Results from this study revealed that participants improved their behaviors with the implementation of the intervention (appropriate behavior program), generating positive changes in students' attitudes and social skills during physical education class. In relation to children gender, girls had better scores than boys in relation to appropriate behaviors when losing. Further, when comparing students' age, those from 10 to 11 years old scored higher in fair play behaviors and social skills. In conclusion, the intervention program was effective to improve the behaviors of the school children, generating positive changes in their attitudes and social skills during physical education.

Keywords: appropriate behaviors, social skills, games, sports, physical education, elementary education, fair play

\section{INTRODUCTION}

Focusing on the development of values and appropriate social skill during physical education and sports is extremely important (Samalot-Rivera, 2007; Samalot-Rivera and Porretta, 2012). Physical education is considered one of the school topics with the potential to develop these behaviors (Moore et al., 1995; Vidoni, 2003; Ponce, 2006; Samalot-Rivera and Porretta, 2009, 2012). For years now, physical education and sports had been considered appropriate context to develop a healthy lifestyle, including the development of appropriate behaviors, values and social skills (Hellison, 2003). Further, physical education is seen as one of the schools' subject with greater impact of mental, emotional and physical development of students (Ponce, 2006). Weinberg (2011) mentions that the participation in sports, facilitate numerous interpersonal relation situations and the development of interpersonal and social skills.

Learning to co-exist should be one of education main objectives. We must promote values like tolerance, solidarity, and mutual respect though the physical education class because is an 
appropriate and ideal environment to achieve this (Eldar et al., 2006; Gil-Madrona et al., 2006). The physical education curriculum offers specific opportunities, that are not possible in other subjects (Siedentop, 1991; Laker, 2000; Siedentop et al., 2004).

Bloom and Smith (1996) and Hellison (2003) mentioned that neither teachers or coaches can assume that children will learn values and social skills by just participating in the activities without the proper planning and implementation during physical education and sports. Further, VelázquezCallado (2004) consider that teachers who choose to teach using cooperative activities help students learn the objective of the activities and developing simultaneously social skills, auto control skills and empathy toward their peers in the physical education class.

During the last years, there had been an increasing interest to examine the effect of physical activity and sport programs on students' social development experiences during the physical education class. Cooperative learning had been one of the programs used by Fernández Río (2003), in wish he demonstrated improvements on student's social abilities like trust, enjoyment, and friendship using cooperate learning activities. Cecchini et al. (2008a) found out that physical activity offers a unique opportunity for peer interaction, respect and tolerance. For this reason, all personnel working with students or athletes, should have the proper training to implement and teach these values. This had inspired many researchers during the last decade to develop and design intervention programs to promote the moral development of students and athletes during physical education class and sport related activities (Escartí et al., 2005, 2006; Ruiz et al., 2006).

Gil-Madrona et al. (2016), examined the effectiveness of a physical education program focused on the teaching of social skills and values, fair play, social relationships, effort, selfdiscipline, and self-control in the social affective context on students from 6 th to 8 th grade. They concluded that when social abilities and values interventions are implemented, students improve their knowledge about how to positively behave in their physical education class and physical activity context. Further, Danish and Nellen (1997) who presented a model for the development of skills for life, with the objective of using physical activity and sport for the development of personal and social competencies in children and youth, defend that psychosocial acquired abilities can be transferred to other domains as long as the experiences are designed and focused with same purpose (Madrid-López et al., 2016). However, the transfer of the acquired qualities in sport to other areas of life is a controversial topic and has not been proven yet (McPherson, 1986; Heinemann, 1992; García Ferrando et al., 2017).

Some studies had focused on comparing the attitudes of males and females on sport. For example, Derry (2002) affirms that literature demonstrate boys caring more about playing and winning, and girls are more interested in learning the proper ways to play, what implies having better skill and tactic development, and social interactions. We must take this evidence in consideration when planning social skill instruction and change behaviors during the physical education class.
The purpose of this study was to know the effects of a program named Delfos (Cecchini et al., 2008a,b), in relation to the improvement of appropriate behaviors during and after physical activity or sport, fair play and social skills. The program Delfos is a pedagogical intervention program designed to develop appropriate behaviors when winning, appropriate behaviors when loosing, appropriate behaviors during the game, fair play skills and social skills, in youth during physical education class. To our knowledge, this is the first study analyzing these aspects in Castilla-La Mancha (Spain).

\section{MATERIALS AND METHODS}

\section{Participants}

Sample was composed of 204 students from 5th $(21.7 \%)$ and 6 th $(78.9 \%)$ grade, between 10 and 13 years old $(X=11.22$; $S D=0.70$ ) with $46.1 \%$ girls and $53.9 \%$ boys. Students were from seven different public schools in Albacete Spain. Sample selection was done by convenience. All public schools from urban and disadvantage areas from Albacete Spain were taken in consideration. All subjects gave assent and their parents provided their informed consent for inclusion before they participated in the study. The protocol was approved by the University of Castilla-La Mancha Research Ethics Committee and by the Ethics Committees of the schools participating in the study.

\section{Data Collection}

A validated questionnaire titled Appropriate Behaviors in Physical Education and Sport by Samalot-Rivera and Madrona, was used to collect data in this study. This questionnaire is composed by 32 items with a 5 level Likert scale (1- Never, 2-Sometimes, 3-Occasionally, 4- Most of the Time, and All the Time). The items were grouped from a theoretical point of view and were divided in the following groups: appropriate behaviors when winning, appropriate behaviors when loosing, appropriate behaviors during the game, fair play skills and social skills. Reliability of the instrument was measured by Alpha Cronbach obtaining an adequate 0.883 .

\section{Procedures}

An experimental pre and post-test with control groups was used Hernández-Sampieri et al. (2003). The Delfos program was used as the intervention of this study. The Delfos program does have an educative intervention with pedagogical teaching strategies, organization and session designed with the purpose of improving fair play, increase levels of self-control and modify inappropriate behaviors in youth. The principal values associated with Delfos program are student wellbeing, personal development, effort and self-management (Cecchini et al., 2008a,b).

There is no doubt that any program to be implemented, needs to be tested with the purpose of knowing to what extent the program is effective (Hernández-Mendo and Anguera, 2001). For this reason, we decided to test this program to see the effects that have in youth by using a questionnaire about Appropriate Behavior During Physical Education and Sport developed by 
Samalot Rivera and Pedro Gil Madrona, validated by GutiérrezMarín et al. (2017). As part of this program, students needed to complete and sign a behavior contract where they compromise to improve and decrease their aggressive behaviors, eliminate certain conducts of putting other down and increase the capacity to avoid and solve conflicts in sport related activities and in their daily living.

Delfos program structure the physical education classes this way:

(a) Discussion of the social skill: in this phase of the program a discussion about the social skills to be worked was conducted. A discussion of the attitudes and social skills expected as part of the program objectives and values took place.

(b) Activation phase: in this phase of the program the focus was on providing students the opportunity to be physically active.

(c) Confrontation phase: in this phase, students were given constant feedback about their behaviors during class.

(d) Reflection phase: in this phase is when teachers and students analyze possible moral conflicts during the class sport or activity played and come up with solutions.

(e) Transition phase: the objective of this phase was to make sure that students understood the importance of the learned values and social skills will have in their lives. This was discussed during the reflection phase at the end when they were asked to please continue using the discussed and learned values in their communities.

The intervention program was conducted in the physical education class for a total of 20 class sessions of $45 \mathrm{~min}$ each. This program was designed with the purpose to help students learn appropriate sport and fair play behaviors before, during and after games.

\section{Analysis}

A $2 \times 2$ factorial design with pre and post-test design was used for this study. The first factor references student's gender (male and female). The second factor references the age of the participants (10 to 11 and 12 to 13 years old). Participants were measured pre and post treatment. For data analysis SPSS for Windows version 19.0 was used. With the objective to prepare data for the analysis we examined: (a) the patterns on the lost data to estimate if its respond to a random distribution (Tabachnick and Fidell, 2001), (b) the mean, standard deviation, asymmetry and kurtosis of each one of the variables considered in this study, (c) the presence of univariate and multivariate atypical cases, and (d) the presence of multicollinearity among variables (Kline, 2011). As a criterion to evaluate index of asymmetry and kurtoris it was considered to be excellent values between $+1,00$ years $-1,00$, and as fair values inferior to $+2,00$ years $-2,00$. Later, atypical univariate cases were identified through the standard results of each one of the variables $(z>3.29, p<0.001)$.

A Mahalanobis test with $p<0.001$ was conducted with the finality of discard multivariate atypical cases
(Tabachnick and Fidell, 2001). A last analysis consisted of a multicollinearity test between the variables (Kline, 2011), this to estimate the existence of redundant variables $(0.90$ correlations or higher).

A variance analysis of repeated measures (ANOVA) was done. Group and independent factors were gender and age (children between 10 and 11 and 12 to 13 years old). Results obtained between pre and post-test were considered repeated measures. Box's $M$ test was used to compare variation in multivariate samples. Partial square eta $\left(\eta^{2}\right)$ was used to estimate the size effect and the alfa values was set on 0.05 . The effects of the significant interactions given by ANOVA results were explored by a Bonferroni post hoc.

\section{RESULTS}

\section{Data Preparation}

The percentage of the lost cases for not responding to some of the items did not overcome the 5\%. Because this was such a small percentage, it was decided to impute those by a central tendency measurement (mode) of the completed responses of one of the participants in the same scale. This method had demonstrated on lost cases to promote the conceptual attractive balance of precision and simplicity (Shrive et al., 2006). The selection of impute by was due to the fact that we tried to have the five (discrete) response options of the scale. The asymmetry and kurtosis indices of the variables under study were obtained and varied between -1.25 to -0.22 and between -0.34 to 1.84 , respectively, which can be considered as acceptable. Six atypical univariate cases were detected $(z= \pm 3.29)$, of which four are multivariate atypical cases. The elimination of these atypical cases improves the distribution of the variables (indices of asymmetry between -0.93 to -0.24 and of kurtosis between -0.27 to 0.71 ). The correlations between the variables varied between $r=0.24$ to 0.61 , which can be concluded that there are no problems of multicollinearity.

\section{Preliminary Analyses}

A $t$-test of mean difference was applied for independent groups in relation to the age and gender of the participants. Regarding the participants gender, it can be observed that there are significant differences in the variables Social Skills $(d=0.37)$. Female students scored higher on these variables than male students. In relation to age, it can be observed that there are significant differences in the variables Appropriate skills when losing $(d=0.36)$, Fair Play Skill $(d=0.38)$ and Social Skill $(d=0.31)$. The group of students between 10 and 11 years old scored higher on these variables than those students between 12 and 13 years old (Table $\mathbf{1}$ ).

\section{ANOVA of Repeated Measures} Appropriate Behaviors When Loosing

Box's $M$ test was significant $(F=3.182, p \leq 0.001)$, however, Box's $M$ test has been criticized for being overly sensitive for large sample sizes, it can detect even small departures from homogeneity. In other words, it will report a statistically 
TABLE 1 | Mean differences by sex and age group.

\begin{tabular}{|c|c|c|c|c|c|c|c|c|c|c|c|c|c|c|}
\hline \multirow[b]{3}{*}{ Variables } & \multicolumn{4}{|c|}{ Sex } & \multirow[b]{3}{*}{$t$} & \multirow[b]{3}{*}{$p$} & \multirow[b]{3}{*}{$d$} & \multicolumn{4}{|c|}{ Age group } & \multirow[b]{3}{*}{$t$} & \multirow[b]{3}{*}{$p$} & \multirow[b]{3}{*}{$d$} \\
\hline & \multicolumn{2}{|c|}{$\begin{array}{c}\text { Females } \\
(n=93)\end{array}$} & \multicolumn{2}{|c|}{$\begin{array}{c}\text { Males } \\
(n=105)\end{array}$} & & & & \multicolumn{2}{|c|}{$\begin{array}{c}10-11 \\
(n=129)\end{array}$} & \multicolumn{2}{|c|}{$\begin{array}{c}12-13 \\
(n=69)\end{array}$} & & & \\
\hline & $M$ & $S D$ & $M$ & $S D$ & & & & $M$ & $S D$ & $M$ & $S D$ & & & \\
\hline$A B L$ & 20.02 & 3.43 & 19.18 & 3.30 & 1.76 & 0.08 & 0.25 & 20.00 & 3.34 & 18.78 & 3.33 & 2.45 & 0.02 & 0.36 \\
\hline ABW & 19.04 & 3.49 & 18.57 & 3.24 & 0.99 & 0.33 & 0.14 & 18.71 & 3.42 & 18.96 & 3.25 & -0.50 & 0.62 & 0.07 \\
\hline$A B D G$ & 21.42 & 2.56 & 20.94 & 2.63 & 1.29 & 0.20 & 0.18 & 21.23 & 2.55 & 21.04 & 2.70 & 0.49 & 0.63 & 0.07 \\
\hline FPS & 21.69 & 2.40 & 21.26 & 2.80 & 1.16 & 0.25 & 0.16 & 21.81 & 2.39 & 20.81 & 2.92 & 2.58 & 0.01 & 0.38 \\
\hline SK & 53.18 & 4.45 & 51.27 & 5.67 & 2.62 & 0.01 & 0.37 & 52.73 & 4.72 & 51.12 & 5.92 & 2.09 & 0.04 & 0.31 \\
\hline
\end{tabular}

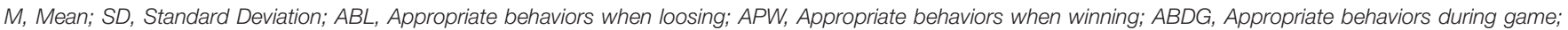
FPS, Fair play skills; SK, Social skills.

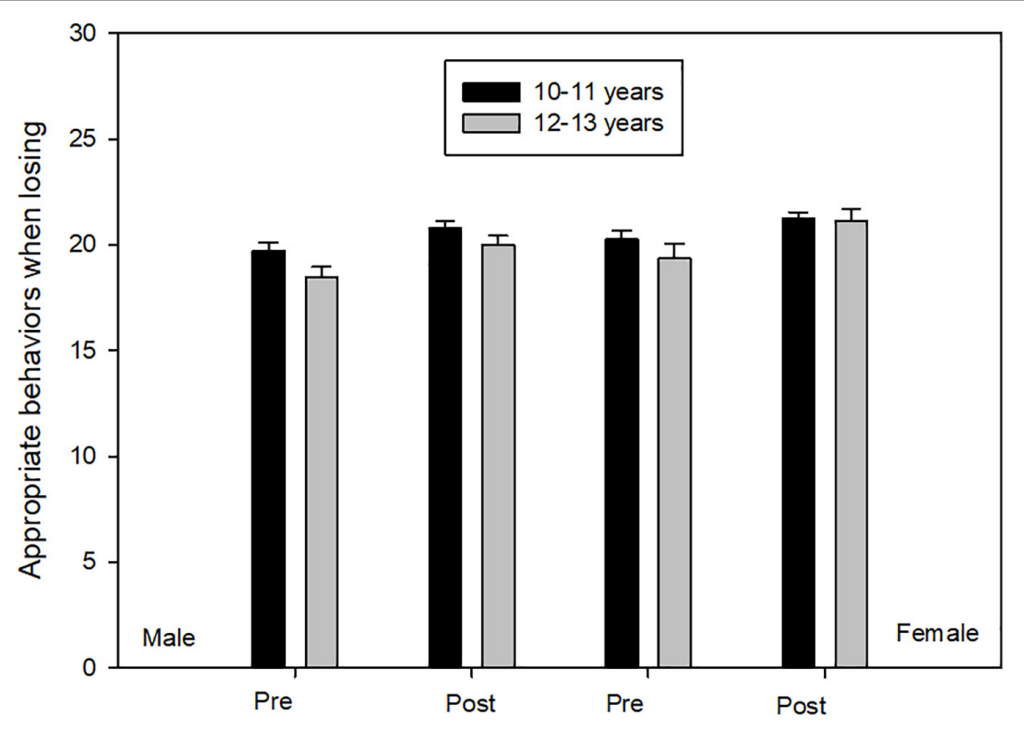

FIGURE 1 | Appropriate behaviors when loosing.

significant result when one does not exist, but they do not increase the probability of type I error (Hahs-Vaughn, 2016). ANOVA measures demonstrated the principal effects of time $\left[F(1,194)=28.689, p \leq 0.01, \eta^{2}=0.13,1-\beta=1.00\right]$ and gender $\left[F(1,194)=3.83, p \leq 0.05, \eta^{2}=0.02,1-\beta=0.50\right]$. Female participants, when compared with male participants, scored significantly higher in appropriate behaviors when losing. In the other hand, post-test scores were significantly higher than pre-test for all four groups (Figure 1).

\section{Appropriate Behaviors When Winning}

Box's $M$ test was no significant $(F=0.424, p \geq 0.92)$. ANOVA scores demonstrated principal effects of time $[F(1,194)=49.095$, $\left.p \leq 0.01, \eta^{2}=0.20,1-\beta=1.00\right]$. Participants scored significantly lower on post-test an all four groups in comparison to pre-test (Figure 2).

\section{Appropriate Behaviors During Game}

Box's $M$ test was no significant $(F=1.356, p \geq 0.20)$. ANOVA scores demonstrated principal effects of time $[F(1,194)=9.944$, $\left.p \leq 0.05, \eta^{2}=0.05,1-\beta=0.88\right]$. Participants scored significantly higher on post-test on all four groups in comparison to pre-test (Figure 3).

\section{Fair Play}

Box's $M$ test was no significant $(F=1.560, p \geq 0.12)$. ANOVA scores showed main effects of Time $[F(1,194)=3.789, p \leq 0.05$, $\left.\eta^{2}=0.02,1-\beta=0.49\right]$ and Age $[F(1,194)=5,540, p \leq 0.02$, $\left.\eta^{2}=0.03,1-\beta=0.65\right]$. Participants aged 10 to 11 , compared to their peers aged 12 to 13 , scored significantly higher on fair play skills. On the other hand, in post test scores, in the four groups, were significantly higher than pre-test scores (Figure 4).

\section{Social Skills}

Box's $M$ test was significant $(F=2.865, p \leq 0.02)$. ANOVA scores showed main effects of Time $[F(1,194)=8,351$, $\left.p \leq 0.01, \eta^{2}=0.04,1-\beta=0.82\right]$, Gender $[F(1,194)=8,717$, $\left.p \leq 0.01, \eta^{2}=0.04,1-\beta=0.83\right]$ and Age $[F(1,194)=3.856$, $\left.p \leq 0.05, \eta^{2}=0.02,1-\beta=0.50\right]$. Participants from 10 to 11 years old, compared to their peers from 12 to 13 years old, scored 


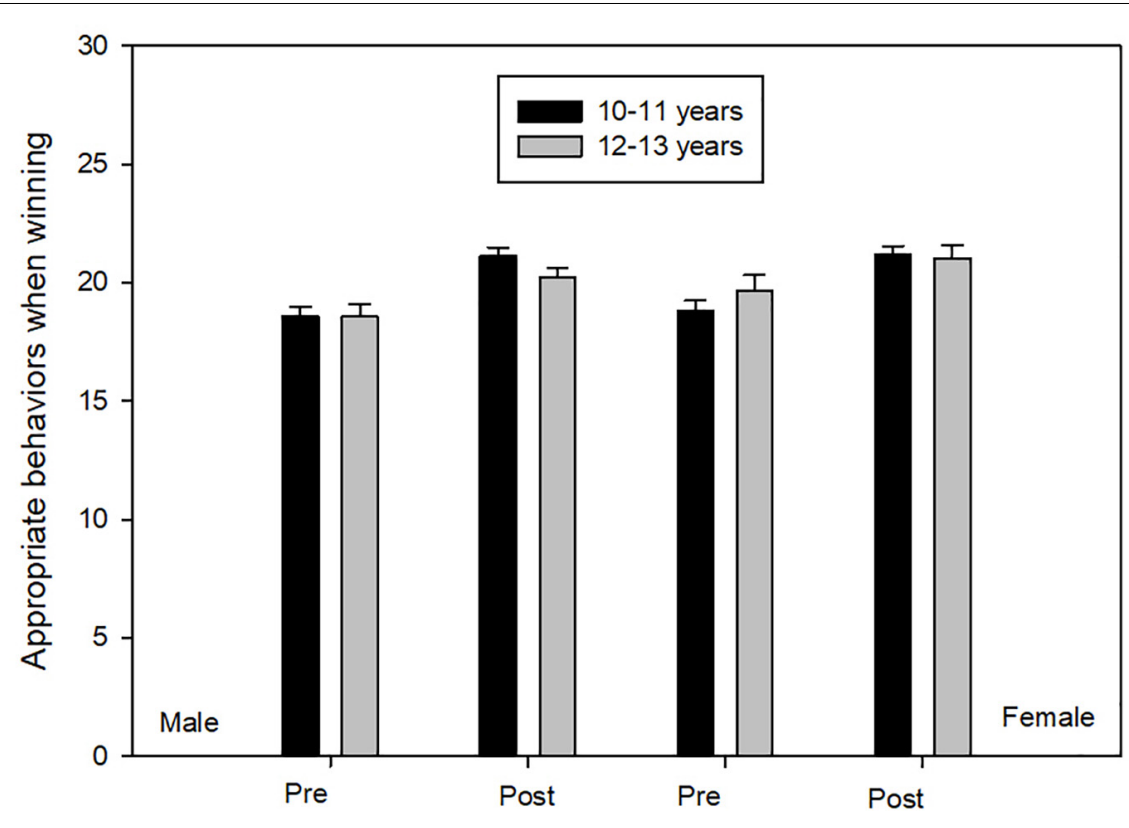

FIGURE 2 | Appropriate behaviors when winning.

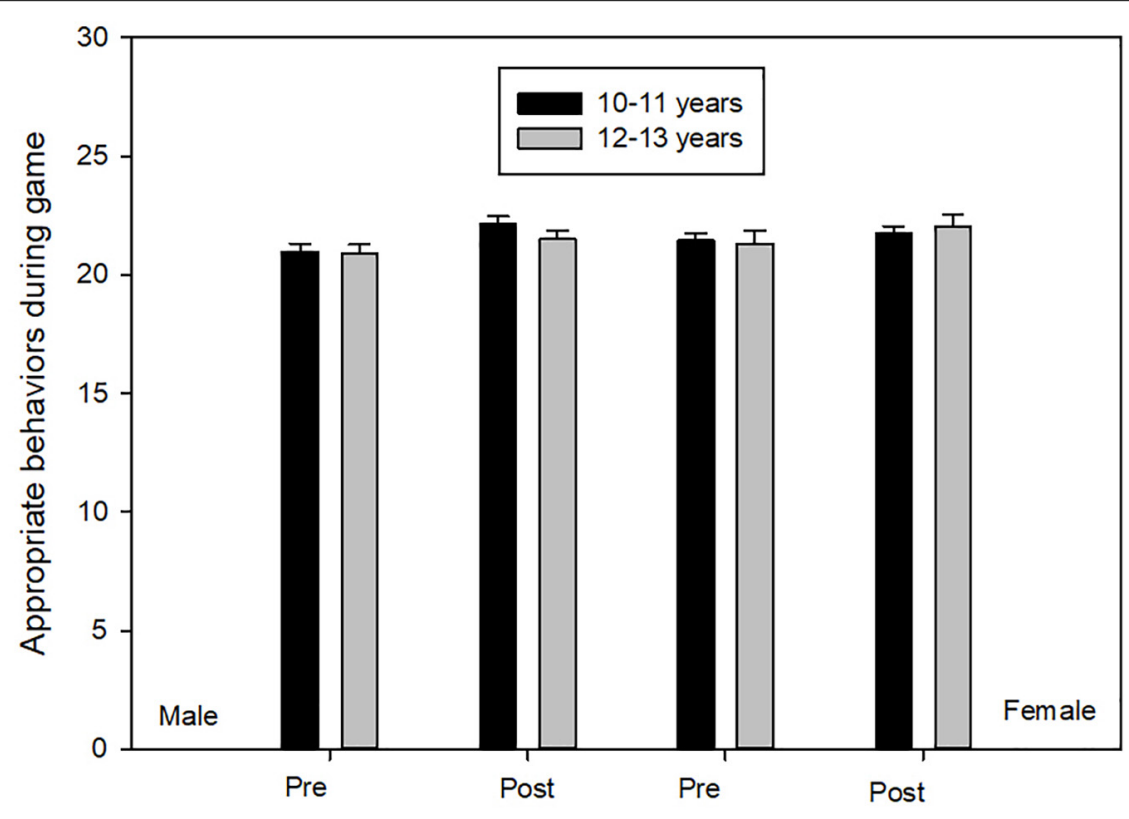

FIGURE 3 | Appropriate behaviors during game.

significantly higher in social skills. However, post test scores, in the four groups, were significantly higher than in the pretest (Figure 5).

\section{DISCUSSION}

This is a novel study because, to our knowledge, this is the first study in Castilla-La Mancha (Spain) analyzing the impact of the program Delfos on students' appropriate behaviors when winning, losing and during games, fair play and social skills in the physical education class. Through this study it can be evidenced the positive impact that the implementation of the program Delfos had on the development and transfer of students' appropriate behaviors when winning, losing and during games, fair play and social skills in the physical education class. Data revealed the improvement of positive attitudes as well as their social skills and fair play versus being carried away with games 


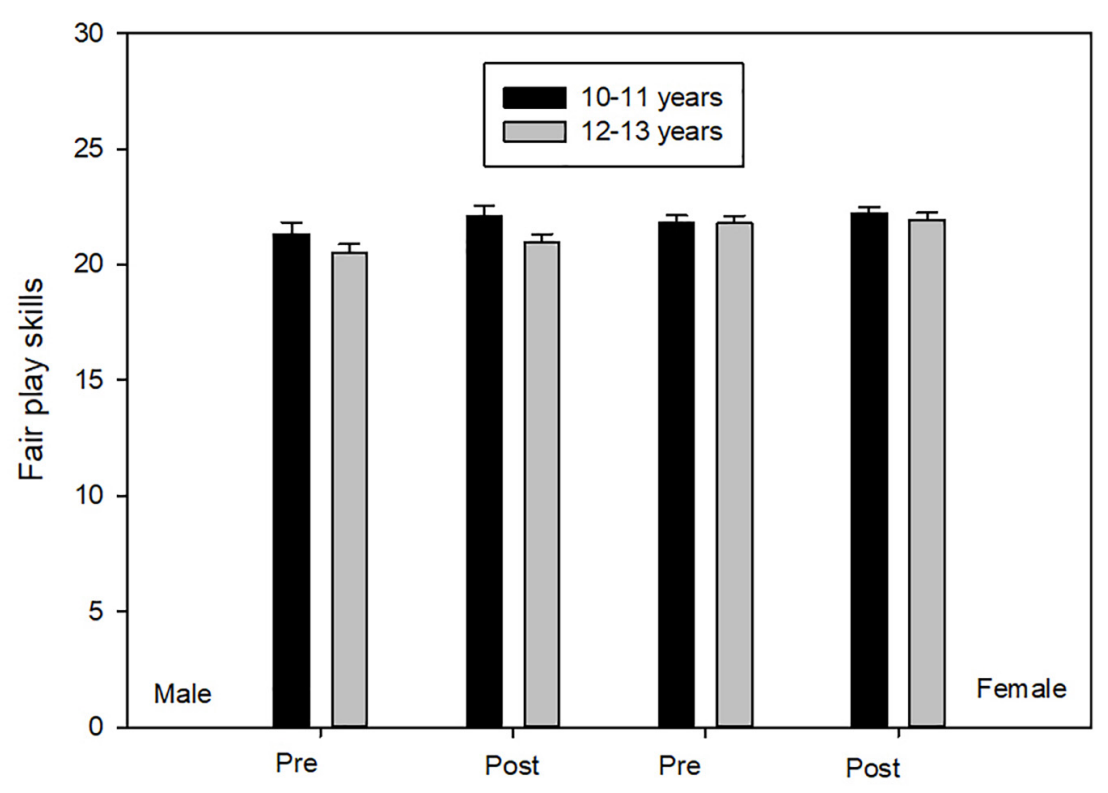

FIGURE 4 | Fair play skills.

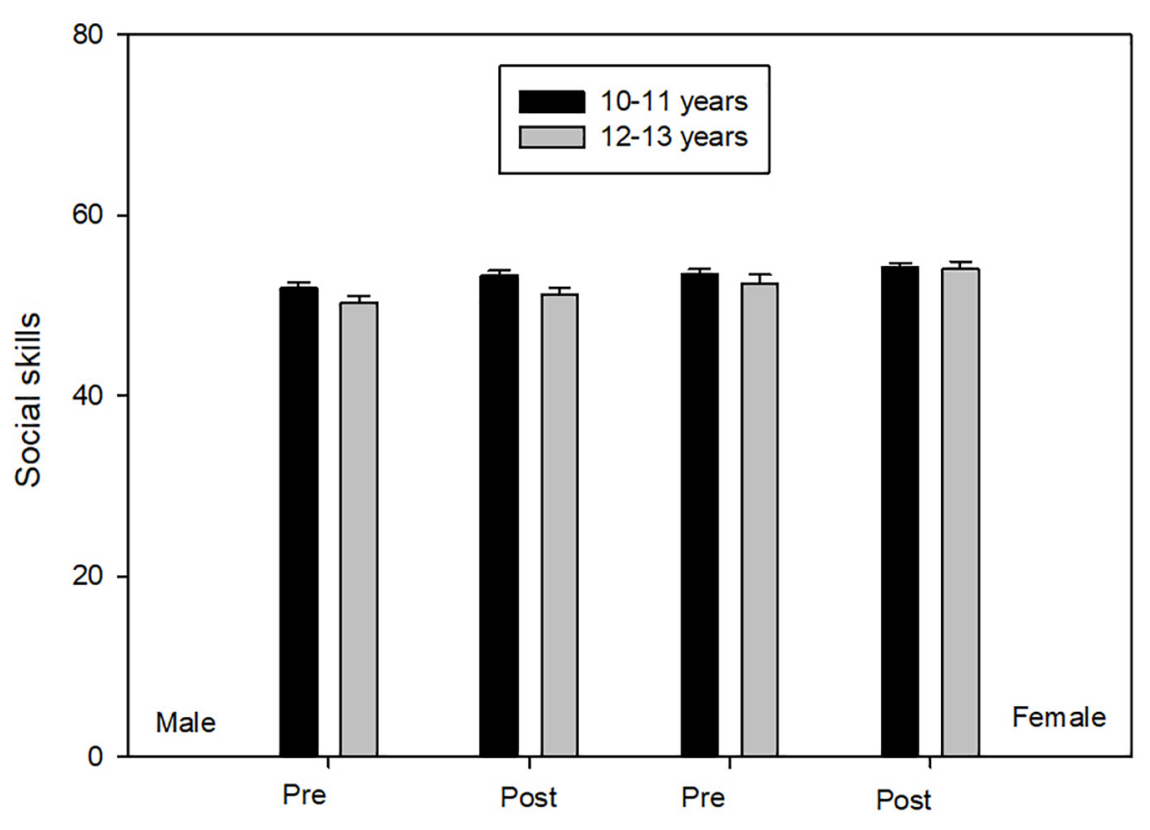

FIGURE 5 | Social skills.

difficult situations and having negative ones. Nevertheless, it is important to consider that previous studies have indicated that the transfer of the acquired qualities in sport to other areas of life is a controversial topic and has not been proven yet (McPherson, 1986; Heinemann, 1992; García Ferrando et al., 2017).

The results of this study demonstrated that students had significantly better scores after the program was implemented. This results provide evidence that playing a sport is not necessarily what help students improve on their behaviors, but rather the context or intervention during the sport activity is what make the difference, helping students to improve their behaviors, values and social skills (Cecchini et al., 2004, 2005). Cecchini et al. (2005), had similar results when they addressed youth at risk behaviors with the same objectives of this study. It is evident that literature provide enough evidence to believe that this type of program can be used as a preventive measure to address problems related to misconduct and lack of social skills and values. 
Changes in attitudes and values (appropriate behaviors) will occur easier when appropriate planning to develop these behaviors in physical activity context are implemented (SamalotRivera and Vidoni, 2015). As mentioned many times in the literature, physical education and sports are attractive environments in which these type of interventions can be implemented creating positive behavior changes in students (Vidoni and Ulman, 2012; Samalot-Rivera and Vidoni, 2015). Further, Brustad and Arruza (2002), mentioned that sports events are a good context to develop social skills and values because it offers many opportunities for decision making and personal interaction.

The main strength of the present study is the implementation and evaluation of Delfos program in a new sample of CastillaLa Mancha (Spain), analyzing its impact on students' appropriate behaviors when winning, losing and during games, fair play, and social skills in the physical education class. This study presents also some limitations. This data does provide good improvement of results from pre and post data after the intervention, but to see the reliability of the program we could have compared to a control group or use a parallel measurement scale to control the differences between pre and post intervention. This study focused on assessing the educational possibilities of sport, but future studies should also assess the educational possibilities of other activities, such as music or art. Finally, new qualitative studies are needed to know if aspects such as class incidents, differences between teachers, or differences between types of schools might affect the implementation of the Delfos program.

\section{CONCLUSION}

Students are an important part of the teaching learning process and must be part of it by interacting with class content, peers and the established classroom rules. This way students will learn how to deal with classroom conflict resolution. In this study we were able to observe positive changes in students' target behaviors after the implementation of the program that consisted of 20 sessions of $45 \mathrm{~min}$ each. It was the objective

\section{REFERENCES}

Bloom, G. A., and Smith, M. D. (1996). Hockey violence: a test of cultural spillover theory. Sociol. Sport J. 13, 65-77. doi: 10.1123/ssj.13.1.65

Brustad, R., and Arruza, J. A. (2002). Práctica Deportiva Y Desarrollo Social En Jóvenes Deportistas, Nuevas Perspectivas Acerca Del Deporte Educativo. Bilbao: Universidad del País Vasco.

Cecchini, J. A., Fernández Losa, J., and González, C. (2008a). Repercusiones del programa Delfos de educación en valores a través del deporte en jóvenes escolares. Rev. Educ. 346, 167-186.

Cecchini, J. A., González, C., Fernández, J., and Arruza, J. A. (2008b). Validación De Un Programa De Intervención Para Erradicar Los Comportamientos Violentos De Los Grupos Ultras En Los Estadios De Fútbol. Madrid: Consejo Superior de Deportes.

Cecchini, J. A., González, C., Carmona, M., and Contreras, O. (2004). Relaciones entre el clima motivacional, la orientación de meta, la motivación intrínseca, la auto-confianza, la ansiedad y el estado de ánimo en jóvenes deportistas. Psicothema 16, 104-109. of the program to help students improve in their values and social skills and not necessarily in their sport related skills. After analyzing survey data, females had higher scores than males in appropriate behavior when losing and overall social skills. On the other hand, when comparing age groups, those students from 10 to 11 years old scored significantly better on fair play and social skills, in comparison to those from 12 to 13 years old. Therefore, we suggest that these competencies may be transferred to other domains and may be maintained over time by implementing programs like this, and we also suggest to measure students' behaviors with the Appropriate Behavior Physical Education and Sport questionnaire overtime. This way teachers might reinforce the development of these competencies for students social and personal well-being (Gutiérrez-Marín et al., 2017).

\section{DATA AVAILABILITY}

The datasets generated for this study are available on request to the corresponding authors.

\section{ETHICS STATEMENT}

The studies involving human participants were reviewed and approved by the Research Ethics Committee of the Public School Calar Del Mundo. Written informed consent to participate in this study was provided by the participants' legal guardian/next of kin.

\section{AUTHOR CONTRIBUTIONS}

All authors listed have made a substantial, direct and intellectual contribution to the work, and approved it for publication.

\section{ACKNOWLEDGMENTS}

We would like to thank all the subjects that participated in this study and Dr. Marcos Cupani.

Cecchini, J. A., González, C., López, J., and Brustad, R. (2005). Relaciones del clima motivacional percibido con la orientación de meta, la motivación intrínseca y las opiniones y conductas de fair play. Rev. Mex. Psicol. 22, 429-479.

Danish, S. J., and Nellen, V. C. (1997). New roles for sport psychologists: teaching life skills through sport to at risk youth. Quest 49, 100-113. doi: 10.1080/ 00336297.1997.10484226

Derry, J. A. (2002). Single-sex and coeducation physical education: perspective of adolescent girls and female physical education teachers (research). Melpomene J. 22, 17-28.

Eldar, E., Morris, D., DaCosta, R., and Wolf, T. (2006). Are you square?” A game for developing self-control and social skills. Strategies 19, 17-21. doi: 10.1080/ 08924562.2006.10591200

Escartí, A., Gutiérrez, M., Pascual, C., Marín, D., Martínez Taboada, C., and Chacón, Y. (2006). Enseñando responsabilidad personal y social a un grupo de adolescentes de riesgo: un estudio «observacional». Rev. Educ. 341, 373-396.

Escartí, A., Pascual, C., and Gutiérrez, M. (2005). Responsabilidad Personal Y Social a Través De La Educación Física Y El Deporte. Barcelona: Graó. 
Fernández Río, F. J. (2003). El Aprendizaje Cooperativo En El Aula De Educación Física Para La Integración En El Medio Social. Análisis Comparativo Con Otros Sistemas De Enseñanza y Aprendizaje. Valladolid: La Peonza.

García Ferrando, M., Lagardera, F., Vilanova, A., and Llopis, R. (2017). "Cultura deportiva y socialización," in Sociología del deporte, 4th edn, eds M. García Ferrando, N. Puig, F. Lagardera, R. Llopis, \& A. Vilanova, (Madrid: Alianza editorial), 69-96.

Gil-Madrona, P., Contreras-Jordán, O., Díaz-Suarez, A., and Lera-Navarro, A. (2006). La educación física en su contribución al proceso formativo de la educación infantil. Rev. Educ. 339, 401-433.

Gil-Madrona, P., Samalot-Rivera, A., and Kozub, F. M. (2016). Acquisition and transfer of values and social skills through a physical education program focused in the affective domain. Motricidade $12,32-38$.

Gutiérrez-Marín, E., Gil-Madrona, P., Prieto-Ayuso, A., and Díaz-Suarez, A. (2017). Conductas apropiadas en Educación Física y el deporte en la escuela y validación de la escala. Cuad. Psicol. Deporte 17, 99-110.

Hahs-Vaughn, D. (2016). Applied Multivariate Statistical Concepts. Milton Park: Taylor \& Francis.

Heinemann, K. (1992). "Socialización," in Diccionario Trilingüe de Ciencias del Deporte, ed. K. Heinemann, (Málaga: Unisport, Junta de Andalucía), 546-548.

Hellison, D. (2003). Teaching Responsibility Through Physical Activity, 2nd Edn. Champaign, IL: Human Kinetics.

Hernández-Mendo, A., and Anguera, M. T. (2001). Estructura conductual en deportes sociomotores: fútbol. Rev. Psicol. Soc. 16, 71-93. doi: 10.1174/ 021347401317351215

Hernández-Sampieri, R., Fernández-Collado, C., and Baptista-Lucio, P. (2003). Metodología de la Investigación, 3rd Edn, Ciudad de México: McGrawHill/Interamericana Editores.

Kline, R. B. (2011). "Convergence of structural equation modeling and multilevel modeling," in The SAGE Handbook of Innovation in Social Research Methods, eds M. Williams, and W. P. Vogt, (Thousand Oaks, CA: SAGE Publications), 562-589. doi: 10.4135/9781446268261.n31

Laker, A. (2000). Beyond the Boundaries of Physical Education. London: Routledge Falmer.

Madrid-López, P., Prieto-Ayuso, A., Samalot-Rivera, A., and Gil-Madrona, P. (2016). Evaluación de una propuesta extraescolar de conductas apropiadas en educación física y deportiva. RETOS Nuevas Tendencias en Educ. Física, Deporte $y$ Recreación 30, 36-42.

McPherson, B. (1986). "Socialization theory and research. Toward a new wave of scholarly inquiry in a sport context," in Sport and Social Theory, eds C. R. Rees, and A. W. Miracle, (Champaign, IL: Human Kinetics), $111-134$.

Moore, R. J., Cartledge, G., and Heckman, K. (1995). The effects of social skill instruction and self-monitoring on 95 game-related behaviors of adolescents with emotional disorders. Behav. Dis. 20, 253-266. doi: 10.1177/ 019874299502000406

Ponce, O. A. (2006). Educación Física Pedagógica, Tiempo Libre Y Calidad De Vida: En Busca De La Efectividad Profesional. Vega Baja: Ponce \& Sons Publications.
Ruiz, L. M., Rodríguez, P., Martinek, T., Schilling, T., Durán, L. J., and Jiménez, P. (2006). El proyecto esfuerzo: un modelo para el desarrollo de la responsabilidad personal y social a través del deporte. Rev. Educ. 341, 933-958.

Samalot-Rivera, A. (2007). The Effects of A Social Skill Instruction on the Sport and Game Related Behaviors of Children and Adolescents With Emotional or Behavioral Disabilities. Ph.D. thesis, The Ohio State University, Columbus, $\mathrm{OH}$.

Samalot-Rivera, A., and Porretta, D. L. (2009). Perceptions and social practices of adapted physical educators relative to the teaching of behaviors. Adapt. Phys. Activ. Q. 26, 172-186. doi: 10.1123/apaq.26.2.172

Samalot-Rivera, A., and Porretta, D. L. (2012). The influence of social skills instruction on sport and game related behaviors of students with emotional or behavioral disorders. Phys. Educ. Sport Pedagogy 17, 1-16.

Samalot-Rivera, A., and Vidoni, C. (2015). Steps to teach appropriate sports and games behaviors through physical education. J. Phys. Educ. Recreat. Dance 86, 8-13. doi: 10.1080/07303084.2015.1022670

Shrive, F. M., Stuart, H., Quan, H., and Ghali, W. A. (2006). Dealing with missing data in a multi-question depression scale: a comparison of imputation methods. BMC Med. Res. Methodol. 6:57. doi: 10.1186/1471-2288-6-57

Siedentop, D. (1991). Developing Teaching Skills in Physical Education. Mountain View, CA: Mayfield.

Siedentop, D., Hastie, P. A., and Van der Mars, H. (2004). Complete Guide to Sport Education. Champaign, IL: Human Kinetics.

Tabachnick, B. G., and Fidell, L. S. (2001). Using Multivariate Statistics, 4th Edn, Needham Heights, MA: Allyn \& Bacon.

Velázquez-Callado, C. (2004). Las actividades cooperativas en los programas de educación física. Reflexiones desde la práctica. Tándem Didáctica de la Educación Física 4, 8-20.

Vidoni, C. (2003). Teaching your class social skills: an explicit strategy. Teach. Elem. Phys. Educ. 14, 20-23.

Vidoni, C., and Ulman, J. D. (2012). The fair play game: promoting social skills in physical education. Strategies 25, 26-30. doi: 10.1080/08924562.2012.1059 2149

Weinberg, R. (2011). "Improving sportsmanship in youth sports: How research informs practice," in Proceedings of the 2nd National Seminar on the Promotion of Sportsmanship and Prevention of Violence in Sports at School Age, VitoriaGasteiz.

Conflict of Interest Statement: The authors declare that the research was conducted in the absence of any commercial or financial relationships that could be construed as a potential conflict of interest.

Copyright @ 2019 Gil-Madrona, Gutiérrez-Marín, Cupani, Samalot-Rivera, DíazSuárez and López-Sánchez. This is an open-access article distributed under the terms of the Creative Commons Attribution License (CC BY). The use, distribution or reproduction in other forums is permitted, provided the original author(s) and the copyright owner(s) are credited and that the original publication in this journal is cited, in accordance with accepted academic practice. No use, distribution or reproduction is permitted which does not comply with these terms. 